\title{
The Body, the Temple and the Newtonian Man Conundrum
} \section{Abstract}

Isaac Newton is considered to be one of the most distinguished scientists and mathematicians in history. According to a recent list of the most influential people in history, Isaac Newton ranks as number 2. For a scientist of the seventeenth-eighteenth century to be so highly revered in the twenty-first century highlights the strength and value of his great scientific works, Optics published 1703 and Philosophiae Naturalis Principia Mathematica published 1687. But he also left a formidable number of unpublished manuscripts which reveals the diversity of his research. As well as his scientific and mathematical works he researched alchemy, theology, prophecy, chronology and he wrote a great deal on the Apocalypse. None of these topics were unusual for a scholar of his era but what made Newton different was the extent and detail of his research. This is also true for his work on Solomon's Temple.

From his early days at the University of Cambridge until his death, Isaac Newton had a long running interest in the Temple of Solomon. The Temple was a topic that appeared in his works on prophecy, chronology and metrology. At the same time that Newton was working on the Principia he reconstructed the Temple and commented on other reconstructions of the Temple. His reconstruction reveals that he was very familiar with Vitruvius' De Architectura and although there is no recorded copy of Vitruvius in his surviving library he does quote and reference him in some of his unpublished manuscripts.

An important part of his reconstruction is the measurements of the Temple. These were harmonic and were built "exactly as the proportion of architectural demand." Newton considered these proportions to be in accordance with Book III and IV of De Architectura. However, while insisting on exact architectural proportions Newton moved away from the traditional proportions of the Vitruvian man that had been an important element in other contemporary reconstructions of the Temple of Solomon. In his work on estimating the length of the Hebrew sacred cubit, the measurement that the Temple was build to, he used another human model; he derived a Newtonian man. This does pose an interesting conundrum; Newton accepted the Temple's architectural proportions as outlined in Vitruvius' Book III yet he rejected Vitruvius' human model used as the foundation of these proportions. At the same time Newton accepted that the human frame was the basis of all ancient measurements and he attempted to estimate the length of the sacred cubit based on the lengths of the parts for the body and the measurements set out by the ancient writers such a Vitruvius. This paper examines this conundrum. ${ }^{1}$

\footnotetext{
${ }^{1}$ There has been some excellent research carried out on the theological implications of the role of the Temple of Solomon in Newton's work (see [Mandelbrote, 1993 \& 2007: Faur; 2004; Goldish,1998]). However, none of these papers have examined Newton's knowledge of architectural and Vitruvian theory. In particular 'A Dissertation upon the Sacred Cubit of the Jews' discussed in this paper, although frequently referenced as proof of Newton's interest in the length of the Jewish cubit (for example [Leshem, 2003: Popkin, 1992: Westfall, 1980]), is a neglected paper that has not been discussed in its own right.
} 


\section{The Temple of Solomon, Babson Ms 0434 and 'A Dissertation upon the Sacred Cubit of the Jews'}

When Newton died in 1727 he left hundreds of unpublished manuscripts some dating back to his early days in Cambridge in the 1660s. Newton's heirs invited Thomas Pellett to examine the manuscripts and report on their suitability for publication. After just three days of examining these hundreds of manuscripts, Pellett dismissed the majority of manuscripts as being 'not fit to be printed [Gjertsen, 1986: 426].' 'of no scientific value' and 'loose and foul papers [Manuel, 1974: 14].' He only found two sets of manuscripts suitable for publication. The first were two manuscripts on prophecies, and although Pellet claimed that the text on prophecy was imperfect, they were nevertheless worthy of publication. This was eventually prepared for press by Newton's nephew Benjamin Smith [Gjertsen, 1986: 399] and published in 1733 as The Observations upon the Prophecies of Daniel and the Apocalypse of St John. Observations proved to be one of Newton's best sellers in the eighteenth century and it was also translated into Latin and German shortly after its first edition [Hall, 1992: 372] .

The second was a set of manuscripts on chronology and these manuscripts were compiled and arranged by John Conduitt, husband of Newton's niece Catherine, and published in 1728 as Chronology of Ancient Kingdoms Amended. The book cannot be considered to be a success and is exceptionally dull. It is arranged in six chapters, five of these chapters were chronologies of the ancient empires of Greece; Egypt; Assyria; Babylon, and Persia. The other chapter is a description of Solomon's Temple, which is not only an intriguing addition to a book on chronology of ancient kingdoms, it is curiously placed after the chapter on the Babylonian Empire, which destroyed the Temple.

The beginning of the chapter on the Temple is quite dismissive: "The Temple of Solomon being destroyed by the Babylonians, it may not be amiss here to give a description of that edifice [Newton, 1988: 332]." The chapter consists of a brief description of its floor plan which is barely 3,000 words long, with three illustrated floor plans. There is no mention of the style of architecture, its splendour or its significance. The description lacks any enthusiasm and is a highly clinical description. Its architectural description has many problems and there are parts that do not make structural sense. For example in the Chronology Newton claimed that;

"The porch of the Temple was 120 cubits high, and its length from south to north equaled the breadth of the House: the House was three stories high, which made the height of the Holy Place three times thirty cubits, and that of the Most Holy three times twenty [Newton, 1988: 342-343].”

Since the porch, the Holy Place and the Most Holy of Holies adjoined each other this description created a strange and confused stepped structure which appears to have no precedents, Biblically or otherwise. The three illustrated floor plans are very detailed but that detail is not backed up by the text. Furthermore both the text and the illustrations include an external wall that surrounds the precinct wall with four gates on the western side, the Gate of Shallecheth, the Gate of Parbar, and the two Gates of Assupim. But they are part of the Second Temple and not Solomon's Temple [2 Samuel 6:11-12].

From this chapter it would be easy to conclude that Newton had no knowledge of architecture and that his interest in Solomon's Temple was only as a biblical symbol and with its destruction being an important historic event. However, the converse is true. Not 
only did Newton have a good working knowledge of Vitruvian theory he had a long running interest in the Temple of Solomon that spanned over fifty years.

Over this fifty years Newton wrote many manuscripts that related to the Temple [for example Newton, undated (a), (c), c mid-1680s \& c1690s]. Two manuscripts are of primary interest for this paper one written in the mid-1680s which Newton entitled Introduction to the Lexicon of the Prophets, Part two: About the appearance of the Jewish Temple but is more commonly known by its called number Babson Ms 0434 and the other is an earlier unpublished manuscript of 1680s an appendix entitled 'De magnitudine cubiti sacri [Newton, c1680s(b)]' which is a part of a draft on Solomon's Temple that developed into Babson MS 0434. In 1737 this appendix was translated from Latin into English and published as 'A Dissertation upon the Sacred Cubit of the Jews', in Miscellaneous Works of John Greaves Professor of Geometry at Oxford [Newton, 1737].

'Dissertation' is a work of metrology. Newton examined the measurements taken by John Greaves (1602-1652), Savilian Professor of Astronomy at the University of Oxford, who conducted a survey of the Pyramids of Giza which resulted in the publication of Pyramidographia in 1646. Greaves measurements in English feet, taken at the Pyramids, were used to calculate the Royal cubits, Memphis cubits and the Egyptian cubits. From Greaves' calculations of the ancient cubits, Newton proceeded to calculate the measurement of the Jewish sacred cubit, which was essential to understanding the Temple structure.

Newton's 'Dissertation' begins: “To the description of the Temple belongs the knowledge of the sacred cubit; to the understanding of which, the knowledge of the cubits of the different nations will be conducive” [Newton, 1737: 405]. Newton used Greaves' measurements of the Great Pyramid and systematically compared them with measurements given by ancient sources such as Herodotus, Vitruvius, Strabo, Josephus, Hesychius of Alexandria, Lucius Iunius Moderatus Columella, Philandrier, Gnaeus Julius Agricola, Publius Clodius Thrasea Paetus, the Talmud and more contemporary writers such as Willebrord Snellius, Samuel Purchas and Juan Bautista Villalpando. Newton also cited from Arabic sources, such as Ibn Abd Alhokm (321-405) [Newton, 1737: 408].

In Babson Ms 0434 Newton systematically reconstructed the Temple of Solomon. His primary source for his reconstruction was the Book of Ezekiel. However, Newton examined the changes in the Temple over time. The building of the second Temple by Zerubbabel followed the same foundations but with a great deal less grandeur. It had the same dimensions and was a pragmatic house of worship but its architecture was mundane and it was nothing to look at [Newton, c1680s(a) 5r]. Cyrus the Great ordered the building of the Temple and the internal atrium but nothing else was added. This was the sanctuary that was maintained up to the time of Alexander the Great as reported by the pagan writer Hecataeus. The Temple was further fortified under Simeon the Just, until Herod built a more sumptuous building for the sanctuary. According to Newton, "God, predicting all these things, thus he corrected them through the prophet Ezekiel [Newton, 1680s(a): 7r]." But Ezekiel did leave out detail of the building and the Angel that revealed the Temple and its measurements to Ezekiel did not show him the entire Temple. Thus by Newton's examination of the architectural features through time and with the writing of ancient writers, such as Philo, Hecataeus, Josephus, Maimonides, the Talmud and the Septuaginta he was able to reconstruct the Temple of Solomon by 
removing the features that had been added by the later builders. He stated "we complete the description of the Temple [of Solomon by] comparing all the Temples between itself and supplying what Ezekiel omitted relative to the Temples of Solomon and of Herod"[Newton, c1680s(a): 59r]. From this description of the Temple, Newton claimed that it is possible to distinguish the plan of the Temple of Solomon. Since Zerubbabel had built on the foundations of the Temple of Solomon, everything that Zerubbabel and Herod added, or anything that is irregular, must be rejected. Symmetry and harmony in the design of the Temple were important factors in the layout of the Temple plan. He stated that, "The structure is valued by such great simplicity and harmony of all its proportions" [Newton, c1680a: 65r].

Babson Ms 0434 is a working document, it is incomplete and it contains two reconstructions; the second one, the more detailed of the two descriptions, is a refinement of the first. The illustration of the Temple precinct in Babson Ms 0434 is in fact the first reconstruction and the second reconstruction is only verbally expressed but in sufficient detail to reconstruct it. In both reconstructions symmetry was of paramount importance to the floor plan.

\section{Newton's Knowledge of Vitruvius, the Measurements of the Body and the Jewish Cubit}

In his reconstruction Newton not only outlined the structure of the Temple he examined the colonnades: the numbers of columns, their height, their thickness, their intervals and their style. These he claimed are determined according to the proportions of architecture. Newton revealed that he was familiar with the architectural theory of Vitruvius' De Architectura, particularly Book III and IV. When Newton derived the width of the inter-columns from the measurement of the column given from Josephus he paraphrased Vitruvius Book III, Chapter III, 'The Proportions of Intercolumniations and of Columns.' He stated "The intervals of these pedestals, according to the proportions of architecture, should not be less than the pedestals [Newton, c1608s(a): 29r]." From Vitruvius, Book IV, Chapter III and the measurements of Josephus, Newton estimated the height of the columns as being "six times the thickness according to the Doric style [Newton, c1680s(a): 36r]." In Ezekiel 40:14 the measurement of the height of the doorway is given as twenty cubits; thus, Newton concluded that "the width of the doorway was of ten cubits and the height according to the rules of the architects, should be double the width [Newton, c1680s(a): 45r; Vitruvius, 1960: IV, vi, 6].” For Newton most of the measurements of the Temple are "exactly to the proportion of architectural demand [Newton, c1680s(a): 10r]." However, according to Newton the architecture of the Temple sometimes surpassed the beauty that classical architecture demands. He confirmed that there was a row of twenty-one columns and twenty inter-columns in the Royal colonnade from the measurement described by Josephus. Newton stated;

the Royal colonnade will occupy seventeen, twenty or twenty-four [spaces] between the columns of the same magnitude. But seventeen, according to the architectural proportions, will be too few, and twenty-four will be excessive if the columns were estimated to be equal to those of the other atriums, and, in one and another case, are set apart too much by the numbers of Josephus, therefore it should be twenty [inter-columns]. According to this proportion, the columns will be less numerous than in the proportion of 
the eustyli of Vitruvius, but more beautiful; and here, where instead of the architrave there are large blocks of marble that cannot be broken, it does not fit the objections of Vitruvius [Newton, c1680s(a): 37r]. ${ }^{2}$

Harmony and symmetry in the design of the Temple were important elements in the layout of the Temple plan. Any element that was described by the ancient writers that was irregular must be rejected. He stated that, "The structure is valued by such great simplicity and harmony of all its proportions [Newton, c1680s(a): 62r]". The perfection of the measurements was of paramount importance to the design.

In Babson Ms 0434 Newton evaluated the measurements revealing their proportional perfection. In the Book of Ezekiel, the prophet is guided by an angel measuring each part of the Temple as they move around the Temple precinct. The measurements of the Temple were in Jewish cubits. There were two types of Jewish cubits which were described by Newton as the sacred cubit and the vulgar cubit. The description of the cubits in Ezekiel is very confusing as he claimed that "The cubit is a cubit and a palm breath", leaving the distinction between the two cubits ambiguous. In 2 Chronicles 3:2, Solomon instructed that the Temple be built in cubits "after the first measure". A cubit was to measure with the length of the forearm from the elbow joint to the end of the middle finger. This simple measurement is inscribed in Egyptian hieroglyphs. The hieroglyph for a cubit is the image of the forearm [Glazebrook, 1931: 413].

In 'A Dissertation upon the Sacred Cubit of the Jews' Newton not only attempted to resolve this ambiguity he also attempted to estimate the length of both cubits. He quoted Vitruvius' measurement of the Roman and Greek cubit as being one and a half Roman feet [Newton, 1737: 405; Vitruvius, 1960: III, i]. A Roman foot is 0.97 of an English foot. Newton examined both the Roman and Greek cubits and feet; measuring them in palms and digits, together with the Greek orgyiae, the span of the arms fully outstretched, because these measurements were defined by the ancient authors. To estimate their value Newton approached the problem of the variations in the measurements of the ancient authors by assessing each one of their limits and then comparing them to each other.

Newton reasoned that the builders of the Great Pyramid would have used a uniform unit of measurement in their design which would have been the ancient measurement of a cubit. In his calculations he claimed that one Greek orgyiae is equal to four Memphis cubits. After converting the measurement of Greaves from English feet to Roman palms and digits he then compared them with the measurements of the ancients. From this Newton concluded, "And it is my opinion that the Pyramid was built throughout after the measure of this (Memphis) cubit [Newton, 1737: 413].” Newton supported this argument that the ancient buildings were built to a standard unit of measurement by considering the measurement of Babylonians bricks. They were all uniform in size, according to the measurements of sixteenth century travel writer Samuel Purchas, their length was one foot, the width was eight inches and the thickness was six inches. So that two bricks in length, three bricks in width and four bricks in thinness formed a square cubit.

He claimed that all measurements which exceeded human proportions, such as the Roman calamus, clima, scruplum, actus and many others, were deduced from the

\footnotetext{
${ }^{2}$ All quotations from Babson Ms 0434 are translated from Latin by the Author.
} 
multiples of human proportions. The ancient nations rounded off their large numbers into even numbers of cubits - the cubit of man [Newton, 1737: 416]. Newton derived the length of many nations' cubits: Memphis, Egyptian, Greek, Roman, Arabian and Babylonian cubits. Although the different lengths of these cubits conformed to the cubits of man, with the exception of the Babylonian cubit which he estimated at two English feet [Newton, 1737: 414], this may be an error of inscription since later in the paper he referred to the Babylonian cubit as being two Roman feet, but both measurements are larger that the human elbow; yet, he still maintained that the Babylonians built in cubits.

Greaves found that the modern Egyptian cubit was 1.824 English feet, exceeding that of the ancient Egyptian cubit or Memphis cubit. "The measurements of feet and cubits now exceed the proportion of the human members [Newton, 1737: 417]". According to Greaves' measurements of the Egyptian monuments, the human stature was the same as it was in ancient times. The measurements had increased in length because of human and instrument error.

"Feet and cubits were used first (as a measurement) in every nation according to the proportion of the members of a man, from which they were taken. For the foot of a man is to the cubit or lower part of the arm of the same man as about 5 to 9 [Newton, 1737: 419]."

Newton confirmed this ratio 5:9 between the foot and cubit with other ancient measurements. He considered that the Jewish measurements were determined in the same manner.

He claimed that the Jewish vulgar cubit cannot exceed the cubit of a tall man. Newton claimed that

"The stature of the human body, according to the Talmud, contains about three cubits from the feet to the head; and if the feet be raised, and the arms lifted up, it will add one cubit more and contain four cubits. Now the ordinary stature of men, when they are bare-foot, is greater than five Roman feet, and less that six Roman feet, and may be best fixed at five feet and an half [Newton, 1737: 421]. ${ }^{3}$

According to Erubin 48a in the Talmud, the area of 'his place' is "three cubits for his body and one cubit to enable him to take up an object at his feet and put it down at his head.” Newton moved away from the classical 'Vitruvian' man. In Vitruvius the height of man is set at six Roman feet; Vitruvius claimed that the number six was perfect and this perfection was further expressed in the Roman cubit which equalled six palms or 24 digits, but to Newton and the Bible six palms was a sacred Jewish cubit. Newton's measurements of the stature of a man, five to six Roman feet, equalled three vulgar Jewish cubits of five palms each cubit; thus a vulgar cubit was to be no less that 20 Roman unciæ ${ }^{4}$ and no more than 24 unciæ, $^{5}$ also from this measurement the sacred Jewish cubit, of six cubits he calculated to be no less that 24 Roman unciæ and no more that 28.8 unciæ.

\footnotetext{
${ }^{3}$ Newton's references to the Talmud are incorrect. His reference is Mishnaioth, Tract. De Ghaburim, cap. 4; it should be Talmud, Erubin, 48a.

${ }^{4}$ A unciæ is a Roman inch, 20 unciæ equals 1.612 English feet

${ }^{5} 24$ unciæ equals 1.934 English feet
} 
Newton gave two examples from ancient literature, where he further defined the limits of the sacred cubit. In the first, Josephus wrote that the columns of the great court of the Jewish Temple could be embraced by three men with their arms joined. Vitruvius stated that "For if we measure the distance from the soles of the feet to the top of the head, and then apply that measure to the outstretched arms, the breadth will be found to be the same as the height [Vitruvius, 1960: III, i, 3]." However, Newton claimed that the orgyia or the length of the outstretched arms of a man, was supposed to be the same as the height of a man but in fact it was a palm wider [Newton, 1737: 422]. Newton abandoned the traditional image of Vitruvian man, which is confined by the circle and the square, by adding an extra palm to the length of a man's outstretched arms giving a slightly more elliptical and rectangular image to the geometry of man (see Figure 1). The circumference of the columns, according to the Talmud and Josephus is eight cubits, for Newton this is equal to three times the height of a man plus three palms i.e. greater than 15.75 Roman feet and less than 18.75 Roman feet. This further defined the sacred cubit to be greater than two Roman feet and less than two and a third Roman feet.

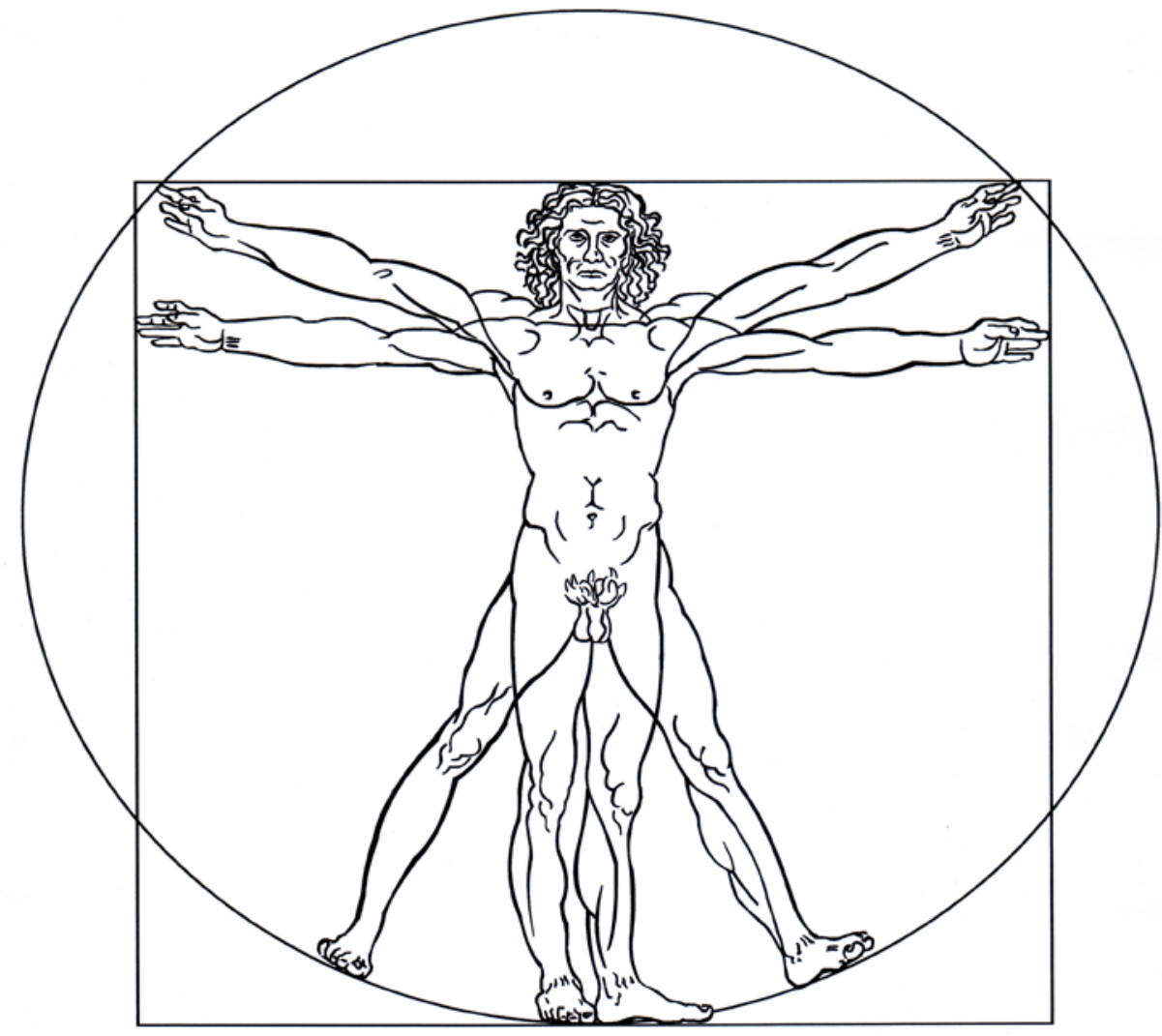

Figure One: The Newtonian Man

In Newton's second example of the use of the cubit from the ancient literature, the Sabbath-day's journey, in the opinion of what Newton called the 'unanimous' content of the Talmud and all the Jews, was two thousand cubits. According to Josephus this measurement is not so consistent, and he claimed that the Sabbath-day's journey is five stades (three thousand Roman feet) and in another place six stades (three thousand-six hundred Rome feet) [Josephus, 1963: V.2.3 \& XX.8.6]. Newton, who was very familiar 
with the work of Josephus, used the reference from the Talmud instead and claimed that instead of 'cubits' the Jews sometime substituted 'paces'. Walking on the Sabbath is not hurried but is of a moderated speed,

Now man of a middling stature, in walking in this manner, go every step more than two Roman feet, and less that two and a third. And within these limits was the sacred cubit circumscribed [Newton, 1737: 424].

Turning to Vitruvius for the correct architectural height of a step [Vitruvius, 1960: III, iv, 4], Newton claimed that the middling proportion referred to by the Jews was about 13.5 unciæ and from this he calculated that a pace or sacred cubit was more that 24 unciæ and less than 27 unciæ. From the examples of the height of a man, the circumference of the columns and the Sabbath-day's walk, Newton defined the limits of the sacred cubit and rejected "the erroneous opinions of other writers". Newton concluded that the vulgar cubit was five palms, the cubit of man which was equal to 21.4 unciæ or 1.717 English feet. While the sacred cubit was six palms [Newton, 1737: 427], the cubit of man plus a palm, was equal to 25.6 unciæ or 2.068 English feet.

\section{The Conundrum of the Newtonian Man}

Unlike many commentators of his time Newton does not directly include or refer to any anthropomorphism element in his reconstruction of the Temple, where the figure of man/God was reflected in the measurements and geometry of the Temple, which prefigured the perfection of the mystical body of the Church. While Newton insisted on exact architectural proportions he moved away from the traditional proportions of the Vitruvian man that had been an important element in other contemporary reconstructions. This does pose an interesting conundrum. Newton accepted the Temple's architectural proportions as outlined in Vitruvius' Book III yet he rejected Vitruvius' human model used as the foundation of these proportions. At the same time Newton accepted that the human frame was the basis of all ancient measurements and he attempted to estimate the length of the sacred cubit with the lengths of the parts for the body and the measurement of ancient writers, such a Vitruvius.

When writing Babson Ms 0434 and 'Dissertation upon the Sacred Cubit of the Jews' he was at the height of his intellectual power and was completing the first edition of the Principia. The rejection of the Vitruvius man as a model for the proportion of the Temple cannot be dismissed as an oversight by Newton. Newton was aware of Book III of De Architectura and the image of the Vitruvian was also well represented in architectural text. Furthermore the images of the cosmological/Vitruvian man were strongly interlinked in the Renaissance with the raise of Hermetic philosophy; and in Newton's unpublished papers he demonstrated an interest in the symbolism of Hermetic philosophy [Newton, undated (a), (b), (c) \& Trismegist, 2002]. The framing of the model from the Book of Erubin in the Talmud and adding a palm to the span of a man's outstretched arms must have been a conscience alternative.

\section{Conclusion}

Newton's manuscripts on the Temple stems over fifty years and the majority of these papers are theological in nature rather than architectural. However, the architecture of the 
Temple plays an important role in the Newton's work on the language of the prophets. The prophets could only be interpreted through hieroglyphs [Newton, 1957] and one of those hieroglyphs was the framework of the architecture and rituals of Solomon's Temple. This view of the Temple is not only confirmed by his unpublished papers but also by Newton's title for Babson Ms 0434 which is Introduction to the Lexicon of the Prophets, Part two: About the appearance of the Jewish Temple. Newton believed that the ancient religion, which he claimed was the original religions of God, understood the mathematical principle of God's orderly design that sustained the solar system. He perceived that they had a pure knowledge of the workings of natural philosophy [Newton, c1690s]. The symbol of the Temple was important to Newton and he returned to the topic many times over the fifty year period. At first he refined it but he eventually sanitized his work towards the end of his life. Before his death, Newton was preparing the Chronology of Ancient Kingdoms Amended for publication; by then he had a legacy to maintain and to maintain that legacy he did sanitize a lot of his work to disguise his religious beliefs [Westfall, 1980: 817] which at the time were heretical and would have seen him publicly disgraced. ${ }^{6}$ The chapter on the description of Solomon's Temple in the Chronology had become so sanitized that it is virtually nonsensical and has lost the former brilliance of his early work.

The conundrum of the Newtonian man is an interesting puzzle but it is one that has no solution for Newton left no clue to why he moved away from the traditional image of the Vitruvian man. However, what Babson Ms 0434 and 'A Dissertation upon the Sacred Cubit of the Jews' does reveal is that he had a good working knowledge of Vitruvian theory and an interest in architectural ascetics which are two aspects of his character that are not normally associated with one of the greatest scientist in history.

\section{References}

ANONYMOUS (Hermes Trismegist). 2002. “Tabula Saragdina”, in The Janus Faces of Genius, ed. B. J. T. Dobbs and trans. Isaac Newton, Cambridge: Cambridge University Press, 274.

BIRCH, Thomas. 1737. Miscellaneous Works of John Greaves London, Printed by J.Hughs for J. Brindley. FORCE, James E. 1985. William Whiston, Cambridge, Cambridge University Press.

FAUR, Jose. 2004. "Newton, Maimonidean”, Review of Rabbinic Judaism 6, no. 2/3. 215-49.

GLAZEBROOK, Richard T. 1931. "Standards of Measurement, Their History and Development”, The Proceedings of the Physical Society 43.

GJERTSEN, Derek. 1986. The Newton handbook, London \& New York, Routledge \& Kegan Paul. GOLDISH, Matt. 1998. Judaism in the Theology of Sir Isaac Newton, London: Kluwer Academic Publishers.

GREAVES, John. 1646. Pyramidographia: Or, a Description of the Pyramids in Aegypt. London. HALL, A. Rupert. 1992. Isaac Newton: Adventurer in Thought, Cambridge: Cambridge University Press. JOSEPHUS. 1963. Jewish Antiquities, IX vols, vol. VIII, London, William Heinemann Ltd. LESHEM, Ayval. 2003. Newton on Mathematics and Spriitual Purity, Dordrecht ; Boston Klumer Academic Publishers

MANUEL, Frank E. 1974. The religion of Isaac Newton, Oxford, Cambridge University Press. MANDELBROTE, Scott. 1993. "A Duty of the Greatest Moment: Isaac Newton and the Writing of Biblical Criticism” The British Journal for the History of Science 26, no. 3, 281-302.

\footnotetext{
${ }^{6}$ William Whiston, former pupil and successor to Newton as Lucasian Professor at Cambridge, also shared Newton's beliefs. However, he made his beliefs public, which ended his career at Cambridge. He was later charged with heresy and although not convicted he ever held an academic position again [Force,1985].
} 
2007. "Isaac Newton and the exegesis of the Book of Daniel”, in Die Geschichte der Daniel-

Auslegung in Judentum, Christentum und Islam, eds K. Bracht and D.S. du Toit, Berlin: Walter de Gruyter, 351-75.

NEWTON, Isaac 1988. The Chronology of Ancient Kingdoms Amended, London, Histories \& Mysteries of Man.

— University Library

— undated(b). Irenicum, unpublished manuscript, Cambridge: King's College.

— undated(c). Notes from Ramon Lull, unpublished manuscript, Stanford, California, Stanford University Library.

— - undated(d). Experimenta Raymundi, unpublished manuscript, Cambridge: King’s College.

— - undated(e) Tabula Smaragdina and Hieroglyphica Planetarum, unpublished manuscript, Cambridge, King's College.

- c1680s(a). Babson Ms 0434, unpublished manuscript, Wellesley, Massachusetts: Babson College.

_ c c1680s(b). Drafts Concerning Solomon's Temple and the Sacred Cubit, Yahuda Ms 2.4, unpublished manuscript, Jerusalem, Jewish National and University Library.

—, C mid-mid1680s. The First Book Concerning the Language of the Prophets (Keynes Ms 5), unpublished manuscript, Cambridge: King's College

—, 1690s. The Original of Religions Yahuda Ms 41, unpublished manuscript, Jerusalem: Jewish National and University Library.

— 1737. A Dissertation upon the Sacred Cubit of the Jews”, in Miscellaneous Works of John Greaves Professor of Geometry at Oxford, Londres.

—, 1957. 'Of an universall language’”, translation and commentary Ralph W. V. Elliott, in The modern language review III, 1 (1957), 1-18,

-, 1988. The Chronology of Ancient Kingdoms Amended, London, Histories \& Mysteries of Man.

POPKIN, Richard Henry, 1992.The Third Force in Seventeenth-centry Through, Leiden \& New York: E.J.Brill.

VILLALPANDO, Juan Bautista, and Jerónimo del PRADO. 1604, Ezechielem Explanationes Et Apparatus Urbis Hierolymitani Commentariis Et Imaginibus Illustratus. Roma, 1604

VITRUVIUS. 1960. The Ten Books on Architecture, trans. Morris Hicky Morgan, New York, Dover Publications.

WESTFALL, Richard S. 1980. Never at Rest: A Biography of Isaac Newton, Cambridge, Cambridge University Press. 